\title{
Література
}

1. Гончаренко С. Гуманізація i гуманітаризація освіти / С. Гончаренко, Ю. Мальований // Шлях освіти. - 2001. - № 3. - С. 2. 2. Каранська М. У. Синтаксис сучасної української літературної мови: [навч. посіб.] / М. У. Каранська. - К. : Либідь, 1995. - 312 c. 3. Язык образования и образование языка // Материалы международной научной конференции (Великий Новгород, 11-13 июня 2000 года). - Великий Новгород : НовГУ, 2000. -382 с.

УДК 37.013.42:37

Ірина Сизоненко

\section{АНАЛІЗ РЕЗУЛЬТАТІВ ПЕРЕВІРКИ ЕФЕКТИВНОСТІ ПРОЦЕСУ ПРАВОВОЇ СОЦАЛІЗАЦІЇ ДІТЕЙ-СИРІТ ПІДЛІТКОВОГО ВІКУ В ЗАГАЛЬНООСВІТНІЙ ШКОЛІ-ІНТЕРНАТІ}

Сизоненко І. Г. Аналіз результатів перевірки ефективності процесу правової соціалізації дітей-сиріт підліткового віку в загальноосвітній школі-інтернаті.

Статтю присвячено аналізу результатів дослідно-експериментальної перевірки ефективності процесу правової соціалізації дітей-сиріт підліткового віку в загальноосвітній школі-інтернаті. Якісний та кількісний аналіз продемонстрував позитивну динаміку правової соціалізації дітей-сиріт підліткового віку.

Ключові слова: модель, правова соціалізація, показники правової соціалізації, діти-сироти, підлітковий вік.

Сизоненко И. Г. Анализ результатов проверки эффективности процесса правовой социализации детей-сирот подросткового возраста в общеобразовательной школеинтернате.

В статье представлен анализ результатов экспериментальной проверки эффективности процесса правовой социализации детей-сирот подросткового возраста в общеобразовательной школе-интернате. Качественный и количественный анализ продемонстрировал положительную динамику правовой социализации детей-сирот подросткового возраста.

Ключевые слова: модель, правовая социализация, критерии, показатели правовой социализации, дети-сироты, подростковый возраст.

Sizonenko I. G. Analysis of results of verification of efficiency of process of legal socialization of children-orphans teens in general school, boarding school.

In the article the analysis of process of teen-orphans' legal socialization in boardingschool of general education is presented.

Key words: model, legal socialization, criteria, indicators of legal socialization, children-orphans, adolescence.

Загальноосвітні школи-інтернати як державні інститути виховання дітей-сиріт і дітей, позбавлених батьківського піклування, перебувають на стадії реформування, перепрофілювання, орієнтації на пріоритетність сімейних альтернативних форм влаштування дітей-сиріт. Реформаційні процеси, що відбуваються в системі інтернатної освіти, відповідно до Державної цільової соціальної програми реформування закладів для дітей-сиріт і дітей, позбавлених батьківського піклування [1], у період до 2017 року передбачають створення умов для реалізації 
соціальної політики щодо забезпечення державних гарантій і конституційних прав, інтересів кожної дитини, яка потребує державної підтримки та соціального захисту.

Необхідність створення, покращення соціально-педагогічних умов виховання, соціалізації, соціальної адаптації і захисту дітей-сиріт, 3 огляду на потребу удосконалення освітнього потенціалу інтернатних закладів, зумовила організацію науково-дослідної роботи $з$ проблеми правової соціалізації дітей у загальноосвітній школі-інтернаті.

Актуальність зазначеної проблеми доводять сучасні наукові дослідження 3 питань виховання, соціалізації, соціального розвитку та захисту дітей-сиріт. Це наукові доробки Л. Артюшкіної, О. Безпалько, Р. Вайноли, О. Голуб, Н. Заверико, В. Загревої, І. Звєрєвої, А. Капської, І. Ковчиної, С. Коношенка, О. Кузьміної, С. Курінної, Ж. Петрочко, І. Пєші, О. Поляновської, Л. Степаненко, С. Харченка, О. Холоденко, Л. Цибулько та ін. Однак у наукових працях недостатньо досліджено теоретико-практичні засади правової соціалізації дітей-сиріт підліткового віку в загальноосвітній школі-інтернаті та відсутнє експериментальне обгрунтування цієї проблеми.

Mema cmammi полягає в аналізі результатів перевірки ефективності організації процесу правової соціалізації дітей-сиріт підліткового віку в загальноосвітній школіінтернаті.

Дослідницька робота передбачала перевірку ефективності впровадженої моделі правової соціалізації дітей-сиріт підліткового віку в загальноосвітній школі-інтернаті та соціально-педагогічних умов іiі реалізації [2]. Це вимагало вивчення динаміки кількісних змін рівнів правової соціалізації дітей-сиріт, задіяних в експерименті, та оцінку за допомогою методів математичної статистики (критерій узгодженості Пірсона $\chi 2$ - критерій, метод рангової кореляції Спірмена) достовірності результатів експериментального дослідження.

3 метою аналізу дослідної перевірки ефективності впровадженої моделі правової соціалізації дітей-сиріт було проведено порівняльний аналіз даних експериментальної роботи на констатувальному та формувальному етапі експерименту.

Дослідження рівнів правової соціалізації дітей-сиріт після формувального експерименту, вивчення, обчислення й оброблення результатів кількісних змін здійснювалася на основі мотиваційно-правового, когнітивно-правового та регулятивно-правового критеріїв.

Зокрема, порівняльний аналіз даних констатувального експерименту 3 дослідження рівнів правової соціалізації за мотиваційно-правовим критерієм і формувального експерименту 3 розвитку інформаційно-пізнавальних, моральнопізнавальних, поведінкових мотивів у спеціально створених соціально-педагогічних умовах правової соціалізації дітей-сиріт підліткового віку в загальноосвітній школіінтернаті надає підстави стверджувати про значне підвищення рівня правової соціалізації дітей-сиріт.

Результат аналізу рівня сформованості правової соціалізації за мотиваційноправовим критерієм продемонстрував посилення зацікавленості дітей-сиріт експериментальної групи у вивченні правової інформації та усвідомлене ставлення до правових норм, що захищають інтереси дітей. У підлітків спостерігалося стійке позитивне ставлення та повага до закону, упевненість у справедливості права, рівного для всіх дітей, законності як суспільної особистісної цінності, почуття поваги до гідності інших людей, які є рівними учасниками у правовій взаємодії.

Одержані дані підтверджують ефективність упровадженої моделі правової 
соціалізації дітей-сиріт підліткового віку та їі позитивний уплив на підвищення рівня вияву правової соціалізації за представленим критерієм. Це підтверджує позитивна динаміка.

Так, контрольний зріз продемонстрував, що високий рівень правової соціалізації експериментальної групи дітей-сиріт за мотиваційно-правовим критерієм становить $14,56 \%$, а після формувального експерименту він склав $26,73 \%$. У контрольній групі він залишився майже на вихідному рівні. Зазнав позитивних змін і середній рівень: на етапі констатації в експериментальній групі він склав 37,31\%, а після формувального експерименту становив 43,86\%. Зменшився низький рівень від 48,13\% до 29,41\%. Вияви показників мотиваційно-правового критерію контрольної групи за середнім і низьким рівнем залишилися майже без змін.

Подальшу роботу було спрямовано на вивчення та аналіз результатів рівня сформованості правової соціалізації в дітей-сиріт підліткового віку контрольної та експериментальної групи за когнітивно-правовим критерієм до та після формувального експерименту. Порівнюючи результати констатувального експерименту та формувального, що передбачав збільшення правового словникового запасу дітей-сиріт, формування базових соціально-правових знань, розвиток умінь і навичок правової самоосвіти підлітків, було засвідчено позитивну динаміку досліджуваного критерію.

Зазначимо, що такого висновку ми дійшли 3 огляду на те, що діти-сироти підліткового віку експериментальної групи продемонстрували знання основних положень законів (Конвенція про права дитини, Конституція, Закон «Про освіту», Сімейний Кодекс, Цивільний Кодекс тощо), розуміння власних прав та обов'язків, норм взаємостосунків з іншими людьми, володіння базовою правовою термінологією (поняття «право», «закон», «обов’язок», «відповідальність», «законослухняність» тощо). Спостерігалася зацікавленість підлітків здобувати правові знання самостійно, без примусу з боку педагогів, що відбувалось у рольових, ділових іграх, тренінгах, міні-виставах та інших формах правової соціалізації. Варто зазначити, що діти-сироти почали розглядати навчання не як самоціль, а як прагнення здобути нові знання задля застосування їх у майбутній життєдіяльності в соціумі.

Порівнюючи результати сформованості правової соціалізації дітей-сиріт за когнітивно-правовим критерієм до й після експерименту, можемо зробити висновок, що в експериментальній групі на 13,52 відсотків збільшилася кількість дітей-сиріт, які мають високий рівень (з 9,73\% до 23,25\%). Також прослідковується позитивна динаміка середнього рівня сформованості правової соціалізації у підлітків експериментальної групи, на початку експерименту цей рівень склав 33,91\%, а вже по завершенні збільшився до 44,74\%. Окрім того, на 24,35\% зменшилась кількість осіб 3 низьким рівнем. У контрольній групі відбулися несуттєві зміни, у дітей-сиріт із високим рівнем він не змінився взагалі.

Аналіз результатів перевірки рівня правової соціалізації дітей-сиріт підліткового віку в загальноосвітній школі-інтернаті за регулятивно-правовим критерієм відбувався на основі зіставлення даних констатувального експерименту та формувального з розвитку правової просоціальної особистості, яка характеризується соціальною відповідальністю, здатністю відстоювати свої права i свободи, конструктивно взаємодіяти в соціумі, а також 3 відповідним рівнем правомірної поведінки та правової активності.

Аналіз результатів проведеної роботи на етапі формувального експерименту засвідчив уміння дітей-сиріт творчо застосовувати сформовані правові знання, 
швидко знаходити правильні правові рішення в проблемних ситуаціях, вияв ініціативи в різних видах діяльності, уміння відстоювати свої права та правильно доводити власну позицію у процесі спілкування, стійкий позитивний характер взаємодії підлітків з вихованцями школи-інтернату, педагогами, іншими дорослими у правовому полі.

Порівнюючи результати рівнів сформованості правової соціалізації дітей-сиріт підліткового віку за регулятивно-правовим критерієм, можемо зробити висновок, що в експериментальній групі на 18,27\% збільшилася кількість дітей-сиріт, які мають високий рівень за підсумками формувального експерименту. Як засвідчують дані, кількість підлітків експериментальної групи із середнім рівнем збільшилась у порівнянні 3 початком дослідження на 11,44\%. Разом 3 тим, значно зменшилася кількість дітей-сиріт експериментальної групи з низьким рівнем - на 29,71\%. Суттєво нижчою $є$ динаміка рівнів спостерігається в контрольній групі дітей-сиріт підліткового віку, які не були задіяні у формувальному експерименті.

Здійснений аналіз та розрахунки отриманих даних дозволили визначити кількісну характеристику рівнів правової соціалізації дітей-сиріт підліткового віку контрольної та експериментальної групи за трьома визначеними критеріями до та після проведення експерименту.

Отже, проведений формувальний експеримент дав можливість здійснити вивчення й аналіз динаміки рівня сформованості правової соціалізації дітей-сиріт підліткового віку в загальноосвітній школі-інтернаті. Результати аналізу показали позитивні зрушення у правовій соціалізації дітей-сиріт підліткового віку. Так, збільшився відсоток дітей-сиріт з високим і середнім рівнем правової соціалізації. Якщо на констатувальному експерименті до високого рівня правової соціалізації ми відносили $15,81 \%$ (51 дитина-сирота), до середнього- 25,43\% (82 дитини), до низького було віднесено 58,76\% осіб (190 підлітків). То вже після контрольних зрізів результат виявився таким: високий рівень склав 24,85\% (80 осіб), середній - 44,89\% (145 осіб), низький $-30,26 \%$ (98 осіб).

Проведений аналіз і вивчення узагальнених експериментальних даних надають підстави стверджувати, що модель правової соціалізації дітей-сиріт підліткового віку в загальноосвітній школі-інтернаті та соціально-педагогічні умови іiі реалізації, що лягли в основу формувального експерименту, є ефективними та результативними.

Подальша перевірка достовірності отриманих даних після вивчення й аналізу динаміки рівнів правової соціалізації дітей-сиріт підліткового віку в загальноосвітній школі-інтернаті здійснювалася 3 використанням методів математичної статистики кількісного і якісного аналізу емпіричних даних результатів експериментального дослідження, що підтвердили висновок про ефективність упровадженої моделі правової соціалізації дітей-сиріт підліткового віку в загальноосвітній школі-інтернаті і соціально-педагогічних умов іїі реалізації.

Аналіз результатів дослідно-експериментальної перевірки ефективності процесу правової соціалізації дітей-сиріт підліткового віку в загальноосвітній школі-інтернаті надає підстави зробити висновок про позитивну динаміку рівнів правової соціалізації. Дослідження підтверджує правомірність розгляду правової соціалізації як процесу соціально-правового становлення дитини-сироти в умовах соціально-виховного середовища загальноосвітньої школи-інтернату під час цілеспрямованого соціальнопедагогічного впливу на формування правомірної поведінки, стійкої правової позиції, життєвої соціально-правової активності, правової особистості, здатної самостійно орієнтуватися в соціально-правовому просторі соціуму. 


\section{Література}

1. Горошнікова I. Г. Модель процесу правової соціалізації дітей-сиріт підліткового віку в загальноосвітній школі-інтернаті / І. Г. Горошнікова // Збірник наукових праць БДПУ (Педагогічні науки). - Бердянськ : БДПУ, 2012. - № 3. - С. 5460. 2. Постанова Кабінету Міністрів України «Про затвердження Державної цільової програми реформування системи закладів для дітей-сиріт та дітей, позбавлених батьківського піклування»: станом на 17 жовтня 2007 року [Електроний ресурс] // Офіційний сайт Верховної Ради України.- Режим доступу : http://zakon1.rada.gov.ua/laws/show/1242-2007-п.

УДК : 37: $304-37.02 .-37.98$

Олена Смик

\section{ФОРМУВАННЯ ЗДОРОВОГО СПОСОБУ ЖИТТЯ МОЛОДШИХ ШКОЛЯРІВ ЗАСОБАМИ ІГРОВОЇ ДІЯЛЬНОСТІ}

Смик О. К. Формування здорового способу життя молодших школярів засобами ігрової діяльності.

У статті розкрито сутність понять «здоровий спосіб життя», «ігрова діяльність»; представлено результати дослідження впливу ігрових технологій на формування здорового способу життя учнів молодших класів.

Ключові слова: здоров'я, здоровий спосіб життя, гра, ігрова діяльність.

Смык О. К. Формирование здорового образа жизни младшых школьников средствами игровой деятельности.

В статье раскрыта сущность понятий «здоровый образ жизни», «игровая деятельность»; представлено результаты исследования влияния игровых технологий на формирования здорового образа жизни учеников младшых классов.

Ключевые слова: здоровье, здоровый образ жизни, игра, игровая деятельность.

Smyk O. K. Health Promoting of younger pupils by the means of playing.

The article deals with the essence of the concepts of «healthy lifestyle», «game activities»; presents results of influence of the game on a healthy lifestyle of the primary school pupils.

Key words: health, healthy lifestyle, game, gameplay activity.

На сучасному етапі виховання здорового покоління визначається як загальнодержавне завдання, важливість реалізації якого передбачено Конституцією України, законодавчими актами України у сфері охорони здоров'я, Національною доктриною розвитку освіти у XXI столітті, Державними національними програмами «Діти України» і «Планування сім’і», комплексною цільовою програмою «Фізичне виховання - здоров'я нації». Діти все частіше опиняються в зоні ризику: хворіють на застудні захворюванняи, спостерігаються різні форми сколіозу та нервових розладів. Загальне погіршення стану здоров'я дітей значно обмежує можливості засвоєння ними навчального матеріалу, що, у свою чергу, впливає на рівень інтелекту, може гальмувати в цілому суспільний розвиток. Одна 3 причин значного погіршення здоров'я школярів - недостатня проінформованість про способи збереження i зміцнення здоров'я, несформованість культури здоров'я у дітей, низька мотивація до здорового способу життя. Це засвідчує доцільність упровадження в освітньо-виховну 